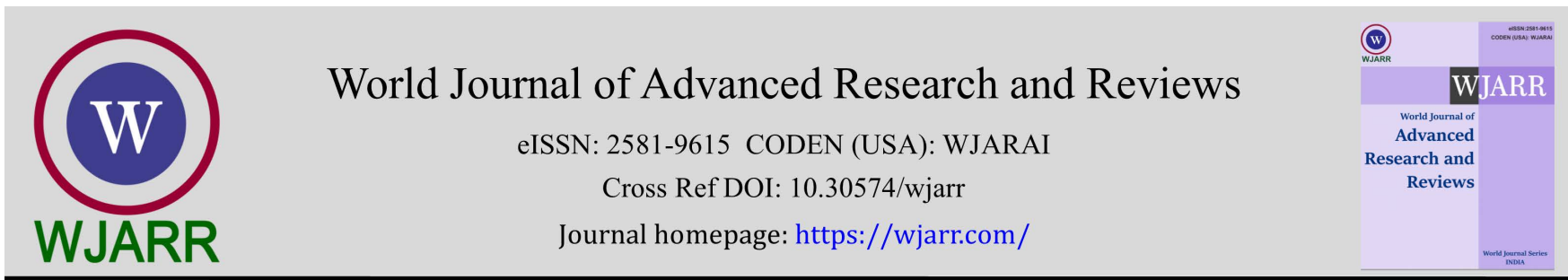

(RESEARCH ARTICLE)

Check for updates

\title{
Assessment of lectinic activity potentials in extracts of some tropical Euphorbiaceace
}

\author{
Odiegwu C.N.C. ${ }^{1}{ }^{*}$, Egbobe C.G. ${ }^{1}$, Ifejirika-Ugboaja E.C. ${ }^{1}$, Ogamba S.E. ${ }^{2}$, Odiegwu C.K.D. ${ }^{3}$ and Ebere \\ Ifejirka Ezeonyi 4
${ }^{1}$ Department of Medical Laboratory Science, College Of Health Sciences, Nnamdi Azikiwe University-Nnewi Campus, Anambra State, Nigeria.
2 Department of Medical Microbiology, Faculty of Medicine, College of Health Sciences, Nnamdi Azikiwe University-Nnewi Campus, Anambra State, Nigeria.
${ }^{3}$ Department of Chemical Engineering, Faculty of Engineering, Nnamdi Azikiwe University, Awka, Anambra State, Nigeria. ${ }^{4}$ Department of Pharmacognosy, Faculty of Pharmaceutical Sciences, Chukwuemeka Odumegwu Ojukwu University, Igbariam, Anambra State, Nigeria.

World Journal of Advanced Research and Reviews, 2021, 10(03), 001-011

Publication history: Received on 10 April 2021; revised on 22 May 2021; accepted on 25 May 2021

Article DOI: https://doi.org/10.30574/wjarr.2021.10.3.0225

\begin{abstract}
Lectins bind a variety of cells having cell surface glycoprotein or glycolipid, such as erythrocytes, leukemic cells, yeast and several types of bacteria. Several specificity groups have been identified such as mannose, galactose, $\mathrm{N}$-acetyl glucoseamine, $\mathrm{N}$-acetyl galactoseamine, L-fucose and $\mathrm{N}$-acetyl neuraminic acid. The presence of two or more binding sites for each Lectin molecule allows the agglutination of many cell type. Sixteen (16) species of some tropical Euphorbiaceae plants were assessed for the presence of Lectins. The leaves of Acalypha torta, Acalypha wiskesiana, Acalypha hispida, Codiaeum variegatum, Euphorbia milli, Euphorbia pulcherima, Jatropha curcas and Jatropha gossypifola; the seeds of Croton tiglium, Ricinus comminus and Tetracarpidium conophorum; the stem of Euphorbia tirucalli and the tubers of Manihot esculenta (Cassava, vitamin A variety), Manihot esculenta (cassava, NR 8082 variety), Manihot esculenta (Cassava, TMX 419 variety), Manihot esculenta (Cassava, TMX 4(2) 1425 variety) were used for sourcing the Lectins. A. torta, A. wiskesiana, C. variegatum, C. tiglium, E. milli, E. pulcherima, E. tirucalli, J. curcas, J. gossypifola, $R$. comminus and $T$. conophorum agglutinated pooled washed human ABO cells in saline (direct haemagglutination) while $A$. hispida and the four varieties of $M$. esculenta showed no agglutination reaction. E. pulcherima showed specificity for B cells only while E. tirucalli showed specificity for 0 cells only, hence could be rightly indicated by referring to them as anti-B Ep and anti-H Et Lectins respectively (where Ep=Euphorbia pulcherima and Et= Euphorbia tirucalli). However A. torta and T. conophorum cross-reacted with pooled washed ABO cells in differing strengths and when standardized, showed that $A$. torta at a titre of 16 reacted specifically with 0 cells and T. conophorum at a titre of 128 reacted specifically with B cells. Based on this, these Lectins could be indicated as anti-H At and anti-B Tc respectively (Where At= Acalypha torta and $\mathrm{Tc}=$ Tetracarpidium conophorum). The protein content of the crude extracts of the sixteen (16) species were also assayed using Biuret protein assay method and the results revealed that there are no relation or association between the quantity of protein content and agglutination patterns of the extracts. This research has therefore succeeded in revealing presence of Lectinic properties in extracts of some tropical Euphorbiaceae.
\end{abstract}

Keywords: Lectin; Potential; Euphorbiaceae; Acalypha torta; glycoprotein

\footnotetext{
*Corresponding author: CNC. Odiegwu

Department of Medical Laboratory Science, College Of Health Sciences, Nnamdi Azikiwe University-Nnewi Campus, Anambra State, Nigeria.
}

Copyright $(2021$ Author(s) retain the copyright of this article. This article is published under the terms of the Creative Commons Attribution Liscense 4.0. 


\section{Introduction}

Lectins are sugar-binding proteins of non-immune origin that binds carbohydrate reversibly and non-covalently without inducing any change in carbohydrate bond. Lectins are found in some plants, particularly seeds and tubers such as cereal crops, potatoes and legumes [1]. Lectins are a complex group of proteins and/or glyco-proteins of non-immune origin possessing at least one non-catalytic domain which binds reversibly and specifically to monosaccharides, oligosaccharides and glyco-conjugates, and they are widely distributed in nature. Lectins exhibit quaternary structure: most are oligomeric, consisting of two to four polypeptide chains with one binding site per chain. Lectins mediate specific transient cell-cell adhesion. Lectins bind a variety of cells having cell surface glycoprotein or glycolipid, such as erythrocytes, leukemic cells, yeast and several types of bacteria. Several specificity groups have been identified such as mannose, galactose, $\mathrm{N}$-acetylglucoseamine, $\mathrm{N}$-acetylgalactoseamine, L-fucose and $\mathrm{N}$-acetylneuraminic acid. The presence of two or more binding sites for each lectin molecule allows the agglutination of many cell type [2]. They associate through the formation of bonds such as hydrogen bond, metal coordinate bond, vanderwaal's and other hydrophobic interactions [3]. Some lectins require divalent cations such as calcium, magnesium and manganese to bind carbohydrates. Others require thiol groups being present instead. Most lectins have covalently linked carbohydrate. The sugar specificity of a lectin is defined by the carbohydrate for which it shows highest affinity. For instance, lectins interact with non-reducing glycosyl groups of polysaccharides and glycoproteins. Some can bind internal sugars or sugars at the reducing end. Some lectins with a small binding site can only recognize one particular monosaccharides; others with extended binding site bind preferentially to trisaccharides or tetrasaccharides [3]. Lectins are important in clinical setting because they are used for blood typing. This is due to the ability of lectins to identify and distinguish carbohydrate determinants on human blood cells. Lectins from Dolichos biflorus is used to identify cells belonging to A blood group. Lectins from Griffonia simplicifolia is used to identify the $\mathrm{H}$ antigen. Lectins can also be used to distinguish secretors from non-secretors [4].

Lectins are ubiquitous proteins and have been isolated from viruses, fungi, bacteria, invertebrates, unicellular organisms, animals and plants [5]. Lectins have become the focus of intense interest for biologists and in particular for the research and applications in agriculture and medicine. These proteins with unique characteristics have founduse in diverse fields of biology and as more lectins are being isolated and their role in nature elucidated, they continue to occupy an important place in agricultural and therapeutic areas of research. The role of lectins include endocytosis and intracellular transport of vector glycoprotein mechanisms [6], induction of apoptosis in tumoral cells [7], blocking of HIV infection [8], regulation of bacterial cell adhesion and migration [9] and control of protein levels in the blood [10]. Lectins are composed of four important sites which accounts for their activities, they include; Metal binding sites, hydrophobic sites, glycosylation sites, carbohydrates binding sites [11]. The specificity of the binding of lectins suggests that there are endogenous saccharides receptors in the tissue from which they are derived or glyco-conjugates with which the lectin is specialized to interact with. Application of lectins can be seen in blood typing, anti-tumor activities, anti-insect activity, anti-viral activity, in biochemical warfare, as mitogens and chemotherapeutic agents.

Lectins have been found in many plant groups including Euphorbiaceae which is a large family of flowering plants with 300 genera and around 7500 species. Most spurges are herbs, but some, especially in the tropics are shrubs or trees. This family occurs mainly in the tropics with majority of the species in the Indo-Malaysian region and tropical America. A large variety occurs in tropical Africa but they are not as abundant or varied as in these two other tropical regions. A number of plants of this spurge family are of considerable economic importance. Prominent plants include cassava (Manihot esculenta), Castor oil plant (Ricinus comminus), Barbados nut (Jatropha curcas), and the Para rubber tree (Hevea brasiliensis). Many are grown as ornamental plants such as poinsettia (Euphorbia pulcherima). In medicine, some species of Euphorbiaceae have proved effective against genital herpes [12].

The ABO blood group system is the clinically most important blood group system which was discovered by an Austrian Scientist Karl Landsteiner in 1900. Landsteiner described the A, B and O blood groups and showed the presence of one of the two antigens either A or B or neither on the red cells of each individual. He also showed thatthe serum from such individual contained different antibodies, example, blood group A contained antibody B, blood group B contained antibody A, blood group 0 contained both A and B antibodies [4]. In 1902 , two of Landsteiner's students Alfred Von Decastello and Adriano Struli discovered the fourth blood type, the AB blood group which contains both A and B antigens on the red cells with no antibody in the serum. The ABO antigens are detectable early in foetal life long before birth but at birth they are fully developed although they are more weakly reacting than adult cells. The reaction between the antigen on the red cells and the corresponding antibody in serum is generally observed in the form of definite agglutination of these red cells [4].

The ABO antigens are the most immunogenic of all the blood groups and thus remain of prime importance in transfusion science. The $\mathrm{H}$ antigen is an essential precursor to the ABO blood group antigens. The H locus is located on chromosome 
19 and it contains 3 exons that span more than $5 \mathrm{~kb}$ of genomic DNA. It encodes a fucosyl transferase that produces the $\mathrm{H}$ antigen on the Red blood cells. The $\mathrm{H}$ antigen is a carbohydrate sequence with carbohydrate linked to protein (with a minor fraction attached to a ceramide moiety). It consists of a chain of B-D-galactose, B-D-N-acetyl glucosamine, B-Dgalactose and 2- linked a-L-fucose, the chain being attached to the protein or ceramide. The ABO locus is located on chromosome 9. These antigens are always found on the red cells and body fluid of secretors and may be mostly glycosphingolipids. The antigens are detectable early in fetal life long before birth but at birth they are fully developed although they are more weakly reacting than adult cells. The blood group terminal sugars are added by specific transferases [4].

The tropics include all the areas of the earth where the sun reaches a point directly overhead at least once during the solar year. The tropics refer to a region of the earth by the equator. It is limited in latitude to the Tropic of Cancer in the Northern Hemisphere at $23.4378^{\circ} \mathrm{N}$, and the Tropic of Capricorn in the Southern Hemisphere at 23.4378 ${ }^{\circ}$. The tropics can also be called the tropical zone and the Torrid Zone. The tropics are associated with the three most significant imaginary lines of the earth viz: the equator, the tropic of cancer and the tropic of capricon. The tropics are distinguished from other climatic and biomatic regions of Earth, which are the middle latitudes and the polar region on either side of the equatorial zone. The tropics comprise $40 \%$ of the Earth's surface area and contain 36\% of the Earth's landmass [13]. Many tropical areas have two major seasons- dry and wet or rainy season. The wet season is the time of the year when most of the average annual rainfall in the region falls [14].

Many families of plants have been studied and found to possess lectinic properties with many useful end applications. However, little or no study of the plants belonging to the Euphorbiaceae family has been carried out in our environment which is a typical example of tropical region. The basic aim of this research therefore was to assess some local Euphorbiaceae plants for the presence of lectins by extracting the seeds, leaves, stems and tubers of some Euphorbiaceae plants family and determine those with lectinic properties by carrying out direct and indirect haemagglutination test on them using fresh pooled washed groups A,B and O Red blood cells.

The specific objectives of this research therefore are:

- To extract the seeds, leaves, stems, and tubers of some tropical Euphorbiaceae plants and determine those with lectinic activities by carrying out direct and indirect haemagglutination tests on them.

- To standardize the extracts that showed different strengths of agglutination reactions with ABO cells with a view to determining the dilution at which the crude extracts can be diluted for profitable Blood Group Serology use.

- To determine the protein contents of the crude extracts with a view to finding out if there is association or relation between degrees of protein content with lectinic properties.

- To explore the viability of commercial production of the extracts with lectinic potentials by deducing the extracts that are at least capable of showing specificity with an ABO cell.

\section{Material and methods}

The seeds, leaves, stems, and tubers of the Sixteen (16) species of the Euphorbiaceace plant family were collected from different farmlands and gardens in Awka and Nnewi and its environs and other parts of Nigeria. These seeds, leaves, stems and tubers were professionally authenticated by an experienced taxonomist at the Department of Botany Nnamdi Azikiwe University, Awka, Anambra State, Nigeria after initial identification at the Department of Botany, Enugu State University of Science and Technology, Agbani, Enugu State, Nigeria.

The Blood samples used for the haemagglutination tests were collected from the Blood bank of Nnamdi Azikiwe University Teaching Hospital Nnewi, and JENIC Clinical \&Molecular Laboratories, Ifite-Awka, Anambra state, Nigeria.

\subsection{Method of Sample Analysis}

\subsubsection{Extraction of Euphorbiaceace Plants Seeds, Leaves, Stems, and Tubers}

Dry leaves of Acalypha torta, Acalypha wiskesiana, Acalypha hispida , Codiaeum variegatum,Euphorbia milii, Euphorbia pulcherima, Jatropha curcas and Jatropha gossypifola, seeds of Croton tigluim, Ricinus comminus and Tetracarpidium conophorum, stem of Euphorbia tirucalli and the tubers of Manihot esculenta (Cassava, vitamin A variety), Manihot esculenta (cassava, NR 8082 variety), Manihot esculenta (Cassava, TMX 419 variety), Manihot esculenta (Cassava, TMX 4(2) 1425 variety) of the species of the Euphorbiaceae plants were crushed into powder using pestle and mortar weighed using Mettler balance and extracted according to the method of Odiegwu et al., 2011 [15]. 


\subsubsection{Protein Assay of the Crude Extracts Using Biuret Protein Assay Method}

This was carried out by mixing $0.02 \mathrm{ml}$ of the standard and $0.02 \mathrm{ml}$ of each of the crude extracts with $1 \mathrm{ml}$ of the Biuret reagent and were allowed to stand for Ten (10) minutes at room temperature and the absorbance were read spectrophotometrically at $546 \mathrm{~nm}$.

\subsubsection{Method of Determining the Lectin Potentials of the Crude Extracts.}

Two (2) haemagglutination techniques were employed in carrying out this viz, tile and tube methods.

Tile Method

- A drop of the $5 \%$ suspension of the pooled washed A, B and 0 cells were placed on a dried white tile.

- A drop each of the crude Euphorbiaceae extracts were placed in each of the 5\% suspension of the pooled washed A, B and 0 cells.

- These were mixed and rocked back and forth.

- Presence of agglutination were checked both macroscopically and microscopically using x10 objective with the condenser iris sufficiently closed.

Tube Method

- Two (2) drops of $5 \%$ suspension of the pooled washed A, B and 0 cells were placed into different tubes labeled $\mathrm{A}, \mathrm{B}$ and $\mathrm{O}$ respectively.

- Two (2) drops of each of the crude extracts were placed in each of the labeled tubes and mixed well.

- The set up was incubated at room temperature for 1 hour.

- The above steps were repeated for all the crude extracts.

- Presence of agglutination were observed both macroscopically and microscopically using x10 objective with the iris condenser sufficiently closed.

\subsubsection{Further Testing}

All the crude extracts that did not produce visible agglutination with the Red cell suspended in saline, were tested using $30 \%$ Bovine albumin and Anti-human globulin (AHG) technique as follows:

Indirect Haemagglutination Test Using 30\% Bovine Serum Albumin (BSA)

- One (1) volume of each of the crude extracts was mixed with one volume of $5 \%$ suspension of washed pooled $\mathrm{ABO}$ cells in a tube.

- The tube was incubated at $37^{\circ} \mathrm{C}$ for 1 hour.

- A drop of $30 \%$ Bovine albumin was layered gently into the tube.

- The tube was incubated further at $37^{\circ} \mathrm{C}$ for 30 minutes.

- The tube was then examined for agglutination macroscopically and microscopically.

- The above procedures were repeated for each of the crude extracts.

Indirect Haemagglutination Test Using Anti-Human Globulin (AHG) Serum

- Three (3) volumes of 5\% suspension of red cells of washed pooled groups A, B and O Rhesus 'D' positive cells was added to three (3) volumes of the crude extracts in a tube.

- The tube was incubated at $37^{\circ} \mathrm{C}$ for 1 hour.

- The content of the tube was washed three times and $10 \%$ suspension was made.

- Two drops of AHG was added to the tube and the tube was spun for a few seconds at $1500 \mathrm{~g}$.

- The tube was then examined for agglutination both macroscopically and microscopically.

- The above procedure were repeated for each crude extracts under investigation.

Standardization of Extracts that Cross Reacted with ABO Cells in Different Strength.

\subsubsection{Procedure}

- Eleven (11) test tubes labeled A were set up for test and control.

- From tube two, three (3) drops of normal saline was added to each tube using a Pasteur pipette.

- Three (3) drops of the extract was then added to tube 1 and 2, tapped to mix and three (3) drops from tube 2 were transferred to tube 3 . 
- $\quad$ The contents of tube 3 were mixed and three (3) drops weretransferred to tube 4 . This was continued up to tube eleven (11) and three (3) drops from tube eleven (11) were discarded.

- The above set ups were repeated in two sets of Eleven (11) test tubes labeled B and 0 respectively.

- $\quad$ Three (3) drops each of 5\% cell suspension of the pooled, washed A, B and 0 cells was placed into the tubes labeled $\mathrm{A}, \mathrm{B}$ and $\mathrm{O}$ respectively.

- The contents of the tubes were mixed properly by tapping the tubes and left to stand at room temperature for one hour.

- The tubes were checked for agglutination macroscopically and microscopically by streaking the cells on slide which was viewed with a microscope using x10 objective with the condenser iris sufficiently closed.

- The last tube that showed definite agglutination in each of the crude extracts against A, B and 0 cells was noted and taken as the Titre (Odiegwu et al., 2011).

\section{Results}

Table 1 shows the direct agglutination test using the Sixteen (16) Crude extract against 5\% saline suspension of pooled washed A, B and O Red Blood Cells.

Table 1 Direct agglutination test using the crude extracts

\begin{tabular}{|c|c|c|c|c|c|c|c|}
\hline $\begin{array}{l}\text { Euphorbiaceace } \\
\text { Plant species }\end{array}$ & Local names & $\begin{array}{l}\text { A- } \\
\text { cells }\end{array}$ & B-cells & $\begin{array}{l}0- \\
\text { cells }\end{array}$ & A-cells & B-cells & 0-cells \\
\hline Acalypha torta & Muel & ++++ & +++++ & clump & $\begin{array}{l}\text { Less than } \\
1 \mathrm{~min}\end{array}$ & $\begin{array}{l}\text { Less than } \\
1 \mathrm{~min}\end{array}$ & $\begin{array}{l}\text { Less than } \\
1 \mathrm{~min}\end{array}$ \\
\hline Acalypha hispida & Chenille plant & - & - & - & - & - & - \\
\hline Acalypha wiskesiana & Fire dragon plant & ++ & - & + & $5 \mathrm{mins}$ & - & 5 mins \\
\hline Codiaeum variegatum & Variegated croton & ++ & + & + & 5 mins & 5 mins & 5 mins \\
\hline Croton tigluim & Purging croton & +++ & +++ & +++ & 5 mins & 5 mins & 5 mins \\
\hline Euphorbia tirucalli & Indian tree spurge & - & - & + & - & - & $7 \mathrm{mins}$ \\
\hline Euphorbia milii & Crown of thorns & ++ & ++ & ++ & 5 mins & 5 mins & 5 mins \\
\hline Euphorbia pulcherima & Poinsettia & - & + & - & - & 7 mins & - \\
\hline Jatropha curcas & Physic nut & ++ & ++ & ++ & $5 \mathrm{mins}$ & 5 mins & 5 mins \\
\hline Jatropha gossypifola & Wild cassava & + & ++ & - & $5 \mathrm{mins}$ & 5 mins & - \\
\hline Manihot esculenta & $\begin{array}{l}\text { Cassava (vitamin } \\
\text { A) }\end{array}$ & - & - & - & - & - & - \\
\hline Manihot esculenta & Cassava(NR 8082) & - & - & - & - & - & - \\
\hline Manihot esculenta & Cassava(TMX419) & - & - & - & - & - & - \\
\hline Manihot esculenta & $\begin{array}{l}\text { Cassava(TMX 4(2) } \\
1425)\end{array}$ & - & - & - & - & - & - \\
\hline Ricinus comminus & Castor oil plant & ++ & ++ & ++ & $7 \mathrm{mins}$ & 7 mins & 7 mins \\
\hline $\begin{array}{l}\text { Tetracarpidium } \\
\text { conphorum }\end{array}$ & African walnut & clump & $\begin{array}{l}\text { Very } \\
\text { strong } \\
\text { clump }\end{array}$ & clump & 2 secs & 2 secs & 2 secs \\
\hline
\end{tabular}

Key :(-) No agglutination (+) Weak agglutination (++) Mild agglutination (+++) Moderate agglutination (++++) Strong agglutination (+++++) Clump agglutination. 
Table 2 illustrates the indirect haemagglutination (30\% BSA) test using the Crude extracts of the Five (5) species that did not react in table 1.

Table 2 Indirect haemagglutination test using 30\% bovine serum albumin for the extracts that did not react in table 1

\begin{tabular}{|l|l|l|l|}
\hline Plant species & A cells & B cells & O cells \\
\hline Acalypha hispida & - & - & - \\
\hline Manihot esculenta (vitamin A) & - & - & - \\
\hline Manihot esculenta (NR 8082) & - & - & - \\
\hline Manihot esculenta (TMX 419) & - & - & - \\
\hline Manihot esculenta (TMX 4(2) 1425) & - & - & - \\
\hline
\end{tabular}

Table 3 depicts the indirect haemagglutination (AHG) test using the Crude extracts of theFive (5) species that did not react in table 1.

Table 3 Indirect haemagglutination test using anti-human globulin for the extracts that did not react in table 1

\begin{tabular}{|l|l|l|l|}
\hline Plant species & A cells & B cells & O cells \\
\hline Acalypha hispida & - & - & - \\
\hline Manihot esculenta (vitamin A) & - & - & - \\
\hline Manihot esculenta (NR 8082) & - & - & - \\
\hline Manihot esculenta (TMX 4(2) 1425) & - & - & - \\
\hline
\end{tabular}

Table 4 Portrays the standardization of Tetracarpidium conophorum (Tc).This Lectin was standardized because it cross reacted with pooled washed $\mathrm{ABO}$ cells in differing strengths and was therefore standardized to find out the dilution at which it is specific to an $\mathrm{ABO}$ cell. From the table it can be deduced that at 1/128 dilution, the Lectin reacted specifically with B cells only and hence its Titre was found to be 128.

Table 4 Standardization of Tetracarpidium conophorum (Tc) Lectin

\begin{tabular}{|c|c|c|c|c|c|c|c|c|c|c|c|}
\hline $\begin{array}{l}\text { Blood } \\
\text { group }\end{array}$ & Neat & $1 / 2$ & $1 / 4$ & $1 / 8$ & $1 / 16$ & $1 / 32$ & $1 / 64$ & $1 / 128$ & $1 / 256$ & $1 / 512$ & $1 / 1024$ \\
\hline A cells & ++++ & +++ & ++ & ++ & + & + & + & - & - & - & - \\
\hline B cells & Clump & +++++ & ++++ & ++++ & +++ & ++ & ++ & + & - & - & - \\
\hline 0 cells & ++++ & +++ & ++ & ++ & + & + & + & - & - & - & - \\
\hline
\end{tabular}

Table 5 Standardization of Acalypha torta (At) Lectin

\begin{tabular}{|c|c|c|c|c|c|c|c|c|c|c|c|}
\hline $\begin{array}{l}\text { Blood } \\
\text { group }\end{array}$ & Neat & $1 / 2$ & $1 / 4$ & $1 / 8$ & $1 / 16$ & $1 / 32$ & $1 / 64$ & $1 / 128$ & $1 / 256$ & $1 / 512$ & $1 / 1024$ \\
\hline A cells & ++++ & +++ & + & - & - & - & - & - & - & - & - \\
\hline B cells & +++++ & ++++ & ++ & + & - & - & - & - & - & - & - \\
\hline 0 cells & Clump & +++++ & +++ & ++ & + & _- & _- & _ & _ & _ & _ \\
\hline
\end{tabular}


Table 5 Reveals that the Acalypha torta (At) Lectin also reacted specifically with 0 cells only at $1 / 16$ dilution and hence the final Titre was found to be 16.

Table 6 demonstrates the protein concentration contents of the Crude extract using the Biuret Protein Assay Method.

The crude extracts of Eleven (11) species (69\%) showed visible aggulutination reactions of varying degrees of avidity, while those of the other Five (5) species (31\%) did not give any reaction with the direct and indirect agglutination tests. The standardization results of the Tetracarpidium conophorum and Acalypha torta Lectin conducted show that they reacted specifically with $B$ and 0 cells at Titres of 128 and 16 respectively. The protein assay results also show that each Crude extract gave different concentration of protein content and have no relation or association with the agglutination patterns of the extracts. The results are as illustrated below.

Table 6 Protein assay of the crude extracts using Biuret Protein assay method

\begin{tabular}{|l|c|}
\hline Test Sample & Protein Content (g/l) \\
\hline Protein standard & 60 \\
\hline Acalypha torta & 25.0 \\
\hline Acalypha hispida & 15.0 \\
\hline Acalypha wikesisana & 15.0 \\
\hline Codiaeum variegatum & 20.8 \\
\hline Croton tigluim & 9.0 \\
\hline Euphorbia pulcherima & 13.8 \\
\hline Euphorbia milii & 15.3 \\
\hline Euphorbia tirucalli & 8.3 \\
\hline Jatropha curcas & 13.5 \\
\hline Jatropha gossypifola & 24.4 \\
\hline Manihot esculenta (vitamin A) & 10.8 \\
\hline Manihot esculenta (NR 8082) & 8.1 \\
\hline Manihot esculenta (TMX 419) & 9.2 \\
\hline Manihot esculenta (TMX 4(2) 1425) & 8.1 \\
\hline Ricinus comminus & 21.8 \\
\hline Tetracarpidium conophorum & 14.4 \\
\hline
\end{tabular}

\section{Discussion}

Lectins are sugar binding proteins of non-immune origin that reversibly bind oligosaccharides of glycoconjugates without enzymatically modifying them. They agglutinate Red blood cells because they recognize and bind specific carbohydrates (saccharides) found on cell surfaces including Red blood cells. The ability of plant Lectins to detect subtle variation in carbohydrate structures found on molecules, cells and organisms has made them a paradigm for proteincarbohydrate recognition. This research was informed by interesting findings on Lectins conducted in developed world and elsewhere as illustrated below:

Yao et al., (2008), examined and established the ability of the legume Lectin, FRIL (Fltz receptor interacting Lectin), extracted from Dolichos specie to preserve neural progenitor cells in suspension culture in vitro. They discovered that FRIL could preserve neural progenitor cells in vitro by inhibiting both cell proliferation and differentiation [16].

Another interesting finding is that of legume Lectin, which is one of the most well studied families of plants proteins that display a degree of carbohydrate specificity. But the lack of frame work to explain their carbohydrate binding specificities has precluded a rational approach to alter their ligand binding activity in a meaningful manner. However, 
the work carried out by Sharma and Surolia sought to provide answers to this problem [17]. Their study reported an extensive analysis of sequences and structures of several legume lectins and showed that despite the hyper variability of their common regions, they exhibit a significant pattern of uniformity within.

Also, Triticum vulgaris lectin or Wheat germ agglutinin (WGA) isolated from Triticum vulgaris (Wheat germ) target the delivery of drug which promotes bioavailability of biologically active substance especially for poorly absorbed compounds and allows the reduction of drug toxicity and interchangeable target potential. Therefore the study of Shen et al., (2011) on Wheat germ agglutinin (WGA), was shown to have potential as a carrier for drug delivery [18].

Mistletoe lectins also have cytotoxic effect on tumor cells by inducing cytokine production by monocytes, which play an important role in cancer growth inhibition [19].

This study was therefore carried out to add to the already rich knowledge base for plant lectins. Sixteen (16) plant species of the Euphorbiaceae family were used for the study. While the seeds of some were used, the leaves, stems and tubers of others respectively were extracted and the extracts were subsequently tested with pooled washed ABO cells to investigate their potentials for lectinic activities. The lectinic activity of each of crude extracts was established based on their ability to agglutinate cells of ABO blood group. Eleven (11) species (69\%) of the sixteen species used for the study showed lectinic activities while the other five (5) species (31\%) did not react in any of the three (3) used serological conditions. The crude extracts of Acalypha torta, Acalypha wiskesiana, Codiaeum variegatum, Croton tigluim, Euphorbia milii, Euphorbia tirucalli, Euphorbia pulcherima, Jatropha curcas, Jatropha gossypifola, Ricinus comminus and Tetracarpidium conophorum showed lectinic activities in that they reacted with pooled washed ABO cells in saline room temperature (direct haemagglutination test) while the remaining five (5) species: Acalypha hispida, Manihot esculenta (vitamin A), Manihot esculenta (NR 8082), Manihot esculenta (TMX 419), Manihot esculenta (TMX 4 (2) 1425) did not show any agglutination reaction with pooled washed ABO cells in saline room temperature, $30 \%$ Bovine serum albumin (BSA) and Anti-human globulin (AHG) serum serological conditions (indirect haemagglutination tests). Two (2) out of the Eleven (11) species that showed lectinic activities in direct haemagglutination test gave specific reaction (reacted with only one cell type); Euphorbia pulcherima reacted with B cells while Euphorbia tirucalli reacted with 0 cells. Thus, they can rightly be indicated by referring to them as anti-BE $\mathrm{p}_{\mathrm{p}}$ and anti-HEt respectively (where $\mathrm{E}_{\mathrm{p}}=\mathrm{Euphorbia}_{\mathrm{f}}$ pulcherima and $\mathrm{E}_{\mathrm{t}}=$ Euphorbia tirucalli). The other nine species cross reacted with more than one cell type; they are Acalypha torta, Acalypha wiskesiana, Codiaeum variegatum, Croton tigluim, Euphorbia milii, Jatropha curcas, Jatropha gossypifola, Ricinus comminus, Tetracarpidium conophorum. The extracts which cross-reacted in different agglutinating strengths were standardized using the serial doubling dilution method to determine the titre at which each of them would react specifically with a particular cell type [4]; [20]; [15]). The crude extracts were diluted from 1 in 1 (neat) to 1 in 1024 and incubated at room temperature. Each of the dilutions were tested with A, B and 0 cells suspension and each of the tubes from neat to 1in 1024 was checked for agglutination macroscopically and microscopically. The last tube that showed definite agglutination for each of the seed extracts against A, B and 0 cells indicate the Titre.

Acalypha torta produced Titre of 4, 8 and 16 against A, B and 0 cells respectively with varying avidities. This implies that at titre of 16, Acalypha torta can be used as Anti-HA diagnostic reagent $\left(\mathrm{A}_{\mathrm{t}}=\right.$ Acalypha torta). Tetracarpidium conophorum produced a titre of $64,128,64$ against A, B and 0 cells respectively with varying degrees of avidity, which implies that at titre of 128 Tetracarpidium conophorum can react specifically with B cells, thus at dilution of 128 it can be used as Anti-BT $\mathrm{T}_{\mathrm{c}}$ diagnostic reagent (where $\mathrm{T}_{\mathrm{c}}=$ Tetracarpidium conophorum). Thus, these two species of Euphorbiaceace lectins can be standardized and used as anti-sera diagnostic reagents and are hence viable for commercial production.

From the protein assay carried out on the crude extracts of the sixteen (16) species of the Euphorbiaceae plants, it was observed that each of the species have a different protein concentration with Acalypha torta having the highest protein concentration of 25.0g/l while Manihot esculenta (TMX 4(2) 1425) and Manihotesculenta (NR 8082) have the lowest protein concentration of $8.1 \mathrm{~g} / \mathrm{l}$. Therefore, the protein concentrations do not have any association or relation with their agglutination pattern. Thus, the various degrees of protein contents of the crude extracts do not influence their agglutination strength or pattern.

These isolated Euphorbiaceace lectins aside from being used for blood grouping can also find use in other areas such as for induction of mitosis [21]; [22], for bacterial pathogen identification [23]; [24], in biochemical warfare [25], as markers in cancer research [26] etc. as lectins have been shown to have numerous end uses applications. 


\section{Conclusion}

The analysis obtained from this research show that:

- Eleven (11) out of the Sixteen (16) species of the Euphorbiaceace plants showed lectinic activities potentials.

- Five (5) out of the Sixteen (16) species of the Euphorbiaceace plants showed no lectinic potentials.

- Euphorbia pulcherima and Euphorbia tirucalli reacted specially with B and O cells and can be indicated as AntiBEp and Anti-HE $\mathrm{H}_{\mathrm{t}}$ lectins respectively.

- Acalypha torta and Tetracarpidium conophorum could similarly be indicated as Anti-HAt and Anti-BTc respectively.

- The agglutination pattern of the species are not necessarily influenced by their protein concentration since there is no association or relation between the protein concentration and lectinic properties.

\section{Recommendations}

Based on the research findings, the following recommendations are advocated:

- Purification of the plant extracts in other to further substantiate their lectinic potentials, facilitate their specificity and deduce their other Medical and Industrial applications.

- The Molecular weight and specific sugar moiety of these isolated Lectins should be deduced with a view to increasing the knowledge about these newly discovered Lectins.

- Immunological assays, Binding tests with parasites, Polymerase chain reaction (PCR) analysis etc. should be carried out on these Euphorbiaceace lectins with a view to determining their other end uses applications.

\section{Compliance with ethical standards}

\section{Acknowledgments}

We hereby acknowledge the corresponding author Re: Dr. C.N.C. Odiegwu for the provision of the much needed expertise, supervision, technology, equipment etc. at his JENIC Clinical \& Molecular Laboratories, Ifite-Awka, Anambra state, Nigeria that enabled this research to be successfully conducted.

\section{Disclosure of conflict of interest}

There is no conflict of interest amongst the authors as all the authors contributed in one way or the other in conducting the research and in writing the manuscript which was eventually articulated and submitted for publication by the corresponding author.

\section{Statement of ethical approval}

This research is in full compliance with ethical standards and moreover, neither human nor animal subjects were used while conducting this research.

\section{References}

[1] Natural therapy pages.com. Lectins and Nutrition. 2012. Accessed, $12^{\text {th }}$ May, 2012.

[2] Cs. Stedwards. Edu. Lectin Structure, Function and Control. 2012. Accessed, 5th May, 2012.

[3] Bio. cmu. edu. The Protein Structure. 2011. Accessed, 22 ${ }^{\text {nd }}$ March, 2011.

[4] Ukaejiofo E.O. ABO blood group, inheritance of the blood group, biochemistry, antigen and antibody of the blood and subgroups. Blood Transfusion in the Tropics. Salem Media Nigeria limited Ibadan. 2009; 1-23.

[5] van Damme EJM, Peumans WJ, Barre A, Rouge P. Plant lectins. A composite of several distinct families of structurally and evolutionary related proteins with diverse biological roles. Critical Review of Plant Science. 1998; 17:575-692.

[6] Yamamoto K. Intracellular lectins involved in folding and transport in the endoplasmic reticulum. Biological and Pharmaceutical Bulletin. 2009; 32:767-773. 
[7] Bah CS, Fang EF, Ng TB, Mros S, McConnell M, BekhitAel D. Purification and characterization of a rhamnosebinding Chinook salmon roe lectin with anti-proliferative activity towards tumour cells and nitric oxide-including activity towards murine macrophages. Journal of Agriculture and Food Chemistry. 2011; 59:5720-5728.

[8] Tanaka H, Chiba H, Inokoshi J, Kuno A, Sugai T, Takahashi A, Ito Y, Tsunoda M, Suzuki K, Takénaka A. Mechanism by which the lectin actinohivin blocks hiv infection of target cells. Proceedings of the National Academy of Sciences USA. 2009; 106:15633-15638.

[9] Tanne A, Neyrolles OC-type lectins in immune defense against pathogens: The murine dc-sign homologue signr3 confers early protection against mycobacterium tuberculosis infection. Virulence. 2010; 1:285-290.

[10] Rydz N, Swystun LL, Notley C, Paterson AD, Riches JJ, Sponagle K, Boonyawat B, Montgomery RR, James PD, Lillicrap D. The c-type lectin receptor clec $4 \mathrm{~m}$ binds, internalizes, and clears von willebrand factor and contributes to the variation in plasma von willebrand factor levels. Blood. 2013; 121:5228-5237.

[11] Barondes SH. Lectins and their multiple endogenous cellular functions. Annual Review of Biochemistry. 1981;15(2):303-306.

[12] Rahman AH. Angiospermic flora of Rajshahi district, Bangladesh. American Journal of Life Sciences. 2013; 1(3):105-112.

[13] Wikipedia.org. The tropics. 2010. Accessed, 20 th March, 2011.

[14] Glossary of Meteorology. Rainy season. 2009; Accessed 20th April 2012.

[15] Odiegwu CNC, Obodozie CC, Okey-Onyesolu CF, Soronnadi CN, Ejike CE. Lectin activities profile of extracts of some tropical Poaceae. Research Journal in Engineering and Applied Sciences. 2011;2(2): 126-131.

[16] Yao H, Xie X, Li Y, Wang D, Han S, Shi S, Nan X, Bai C, Wang Y, Pei X. Legume lectin FRIL preserves Neural progenitor cells in suspension culture in vitro. Clinical and Developmental Immunology. 2008; 6.

[17] Sharma V, Surolia A. Analyses of Carbohydrate Recognition by legume lectins: Size of the combining site loops and their primary specificity. Journal of Molecular Biology. 1997; 267(2): 433-445.

[18] Shen Y, Chen J, ZIU Q, Feng C, Gao X, Wang L, Zhang Q, Jiang X. Effect of wheat germ agglutinin density on cellular uptake and toxicity of wheat germ agglutinin conjugated PEG-PLA nanoparticles in Calu-3 cells. International Journal of Pharmaceutics. 2011; 413: 184-193.

[19] Pryme IF, Dale TM, Tilrem P. Oral Mistletoe lectins: a case for their use in cancer therapy. Cancer Therapy. 2007; 5: 287-300.

[20] Dutta AB. History, Inheritance, Antigens and Antibodies of ABO blood group system. Blood banking and transfusion. $1^{\text {st }}$ esdition. CBS publisher: New Delhi India. 2006; 67-74.

[21] Nowell PC. Phytohaemagglutinin as initiator of mitosis in culture of normal human leucocytes. Calicut. Medical Journal. 2008; 6(1): 2-11.

[22] Kilpatrick DC. Use of lectins as mitogen for lymphocytes. Methods in Molecular Medicine. 1998;9(4):139-144.

[23] Slifkin M, Doyle RJ. Use of lectins as taxonomic markers of specific microorganism. Clinical Microbiology Reviews. 1990; 3(3):197-218.

[24] Amuk H, Sean O, Hrim S, Wadstrom T, Mikelsaar M. Characterization and differentiation of lactobacilli by lectin typing. Journal of Medical Microbiology. 2001; 50(12):1069-1074.

[25] Komath SS, Kavitha M, Swammy MJ. Beyond carbohydrate binding. Organic and Biomolecular Chemistry. 2005; 14(11): 4973-9888.

[26] Ye X.Y., Ng T.B., Tsang P. Isolation of a homodimeric lectin with antifungal and anti-viral activities from red kidney beans (Phaselous vulgaris). Iranian Journal of Pharmacology and Therapeutic.2001; 20(5): 367-375. 


\section{Author's short biography}

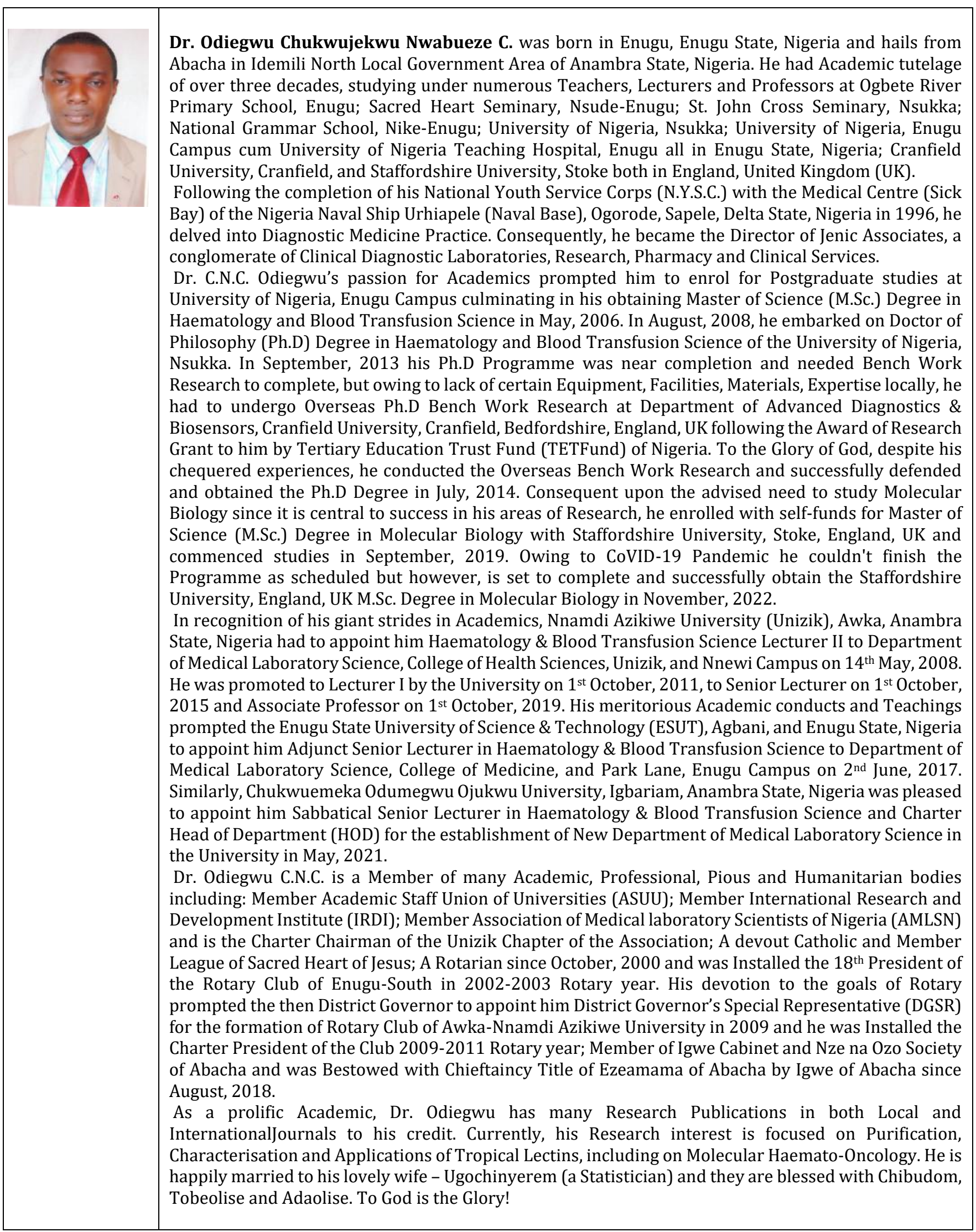

